\title{
THE VALUE OF COMPARATIVE TESTS OF PQROGENIES FROM OPEN-POLLINATED FEMALE ASPARAGUS PLANTS
}

\author{
J. A. HUYSKES \\ Institute of Horticultural Plant Breeding, Wageningen \\ With 1 figure \\ Received 6 March 1959
}

\begin{abstract}
From seed yield determinations in an isolated seed garden the conclusion has been drawn that a male asparagus plant only pollinates those female plants which grow very close to it. The so-called open pollination of a female plant in a commercial or trial field can therefore only be carried out out by a very limited number of male plants.

Comparison of the yield from selected female plants with the yield of those groups of pollinators which belong to these female plants shows that the variations in the production of spears are about equally large. From this it was concluded that the father plants have as large an effect as the mother plants on the characters of progenies of open-pollinated female plants.

Therefore assessment of the genetical value of open-pollinated mother plants on the basis of a progeny test is considered to be unreliable.
\end{abstract}

\section{THE PROBLEM INVESTIGATED}

Asparagus officinalis L., which is grown as a vegetable, is a dioecious crop in which about as many male as female plants occur. As it is propagated from seed cross pollination, which is carried out by insects, is needed. As a consequence the plants in one and the same field show large differences in yield, etc.

Insight in the mode of transmission of these differences is of great importance in breeding. The genetical value of female asparagus plants is sometimes studied as follows. On the basis of certain characteristics, e.g. data on yield and quality, a number of female plants are marked in the field. In the autumn seed is harvested from each of these plants. In accordance with the rules of field plot technique for asparagus (cf. HUYSKES and SNEEP, 2) progenies are raised from these seed samples and included in comparative trials. Those mother plants which yield the best progenies are considered to have the best breeding ability for the characters studied (CURRENCE, 1).

After being propagated vegetatively (2) these plants could be used for seed production or other purposes.

The application of this method has been based on the assumption that the mother plants distributed throughout the field are all pollinated with a pollen mixture of the same genetical value, so that differences between the progenies are attributable to differences between the mother plants. The aim of the investigations reported here has been to find out whether this assumption is correct. 


\section{Material AND MEthods}

Our considerations have been based on observations taken in an isolated seed garden of the above Institute at Wageningen. This garden was established in the woods of the nearby village of Bennekom in 1950. After reclamation the poor sandy soil was provided with stable manure. Next a number of selected female plants were set out in the garden at a distance of $0.45 \times 1.35 \mathrm{~m}$. After every 7 th female plant a place was left open for the insertion of a staminate plant for pollination. To this end homozygous male plants were used to produce an all-male asparagus variety (SNEEP, 4). Pollination was done naturally by insects and also by bee colonies, which were placed in the garden. The dimensions of the garden were $20 \times 20 \mathrm{~m}$. The rows ran about east by west, and a high wire screen fence protected the plants from damage by game. The greatest number of plants, viz. the females, were set out in 1950. The pollen-supplying male plants were sometimes replaced by others before the beginning of a new season. Mostly they belonged to the same clone. In the course of years the crop developed vigorously, partly because it was never harvested. It appeared that pollination was only brought about by pollen of the homozygous male plants, as female plants were never encountered in the progenies. Hence isolation from other asparagus plants must have been very effective.

The aim has been to detect outstanding cross combinations. In addition the present data on pollination have been collected. To this end the berries formed by the female plants were harvested from each plant every autumn. The air-dry seeds obtained from these berries were weighed. The annual seed yields per plant were recorded on a plan of the garden, also indicating the pollinators. In addition to these records the present paper also includes spear yield data per plant from a variety trial field (cf. the discussion).

\section{RESULTS}

In 1956 there was practically no setting of seed, but in 1954, 1955, 1957 and 1958 the seed yield per plant was found to vary considerably at different annual production levels. Female plants spaced $1 \frac{1}{2} \mathrm{~m}$ or less from a male plant had produced much more seed than female plants spaced farther away from a male. As an example the yield is given from three rows in 1955, when there was only one male plant present in the garden (fig. 1). Also when the number of male plants was larger, as in 1954, 1957 and

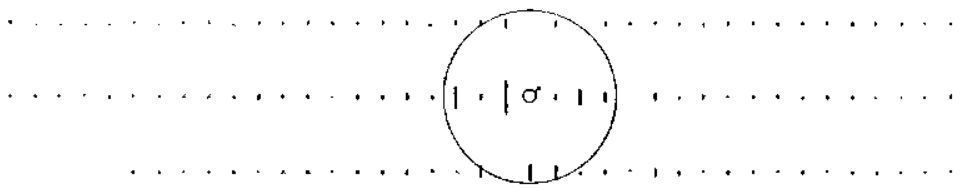

Fig. 1. Seed yield from part of an isolated seed garden in 1955. Three rows of female Plants are SHOWN. THE MALE PLANT IN THE CENTRE ROW WAS THE ONLY POLLINATOR. THE SEED YIELD PER PLANT IS DIRECTLY PROPORTIONAL, TO THE LENGTH OF THE LINE. A POINT REPRESENTS A PLANT WITH LITTLE OR NO SEED; A LINE OF 1 MM CORRESPONDS WITH A PLANT WITH 10 GRAMS OF SEED ETC. 
1958 , such an effect could be clearly observed. Outside the circle with the radius of $1 \frac{1}{2} \mathrm{~m}$ seed setting was usually low. However, within this circle low seed-setting plants also occurred. It appeared that in other years these plants also produced little seed when fertilized by other pollinators, in other words that they lack the character to produce much seed.

The decrease in seed production with increasing distances between the female plants and the male ones can hardly be explained otherwise than by a decrease in the intensity of the pollination. Thus pollination by a male plant is intensive within a circle with a radius of $1 \frac{1}{2} \mathrm{~m}$ and having the male plant in the centre. Outside this circle pollination by this male plant is very slight.

\section{Discussion}

Any female plant in a commercial field is surrounded by male and female plants, since an asparagus field consists half of male plants and half of females. The distribution of both sexes throughout the field is not dependent on certain rules. Consequently pollination is done by a pollen mixture from different male plants. Now it has appeared that intensive pollination by a male plant does not extend further than $1 \frac{1}{2} \mathrm{~m}$ from this plant. Hence a certain female plant can practically only be pollinated by those male plants which occur within a circle with a radius of $1 \frac{1}{2} \mathrm{~m}$ and of which the female plant forms the centre. Within this circle there are, in addition to the female plant in the centre, another 12 plants. On an average six of these will be male, so that each female plant in the field will be pollinated each time by a group of about six male plants. With a heterogeneous crop like asparagus it is not to be expected that a pollen mixture from such a small number of plants will always have the same genetical value.

A statistical approach will confirm this. It has been frequently shown that crosses between high yielding plants also yield productive progenies (THOMSON and RobB, 5, Nagels, 3). The combining ability also plays a part (Currence, 1). The present writer is of the opinion that it is justified to assume a certain relation between the yield and the genetical value, the more so because here we are concerned with the variation and not with the absolute values. It is assumed that the variation between the groups of male plants is a criterion of the variation in the genetical value of the pollen mixtures derived from these groups. This assumption makes it possible to compare the genetical value of groups of male plants which grow in close proximity to the various female plants and consequently pollinate them.

Towork out this problem further, use has been made of yield figures from a certain variety trial field, laid out at the Institute of Horticultural Plant Breeding at Wageningen. This trial field was about $500 \mathrm{~m}^{2}$ and consisted of 625 plants. For three consecutive years the spear yield from each plant was determined every day. On the basis of these and other data some eight choice female plants were selected for breeding purposes. The mean annual yield of these female plants was $378,382,390,399,440$, 506,534 and 651 grams per plant. The groups of male plants which pollinated these females (see above) on an average produced 250, 333, 385, 393, 405, 417, 490 and 546 grams of spears per plant every year. It appeared that the variation in yield in both groups is of the same magnitude. It may be expected that also the genetical value of the groups of father plants and of the mother plants will vary to about the same extent. 


\section{J. A. HUYSKES}

Hence differences in yield between the progenies may be due both to differences in heritable characters of the father groups and to such differences between the mother plants. Consequently any differences in yield are not representative, neither for the male nor for the female side.

From these investigations it may be concluded that assessment of the genetical value of open-pollinated mother plants on the basis of progeny tests is not reliable. This is in agreement with the practice of very experienced asparagus growers which take the pollination into consideration when producing seed. Their practice is to select such choice female plants as are surrounded by good male plants.

\section{SAMENVATTING \\ De waarde van nakomelingschappenonderzoek van vrij bestoven vrouwelijke aspergeplanten}

Uit zaadopbrengstbepalingen in een geïsoleerde zaadtuin is afgeleid, dat een ô aspergeplant alleen de in de onmiddellijke nabijheid staande $q$ planten intensief bestuift. De zgn. vrije bestuiving van een $O$ plant in een praktijk- of proefveld vindt daardoor

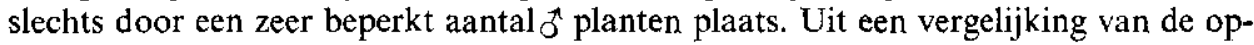
brengsten van geselecteerde $q$ elite planten met die van de bij deze $q$ planten behorende groepen $\sigma_{0}^{\star}$ bestuivers bleek, dat de variaties in de productie van asperges ongeveer even groot waren. Hieruit werd geconcludeerd, dat de invloed van vaderszijde even groot is als de invloed van moederszijde op de eigenschappen van nakomelingschappen van vrij bestoven $O$ planten. Beoordeling van de genetische waarde van vrij bestoven moederplanten op grond van een nakomelingschappenonderzoek wordt daarom niet betrouwbaar geacht.

\section{REFERENCES}

1. Currence, T. M., Vegetable Crops Breeding (Teaching manual). Univ. of Minnesota. 1954.

2. Hurskes, J. A. und SneeP. J., Spargelzüchtung. In: KaPpert, H. und Rudorf, W. Handbuch der Pflanzenzüchtung. Bd. VI. In press.

3. Nagels, W., Met minder kosten meer asperges, 2. Groenten en fruit 8(1953): 940 .

4. SNEEP, J., The significance of andromonoecy for the breeding of Asparagus officinalis L. I and II. Euphytica 2 (1953): 89-95 and 224-228.

5. Thомson, C. J. and Rовв, O. J., Asparagus selections and certain cultural practices compared for yield, earliness and sex ratios. Sci. Agr. 26 (1946): 289-299. 